\section{Lima Bean (Phaseolus lunatus L.) Response to Irrigation Regime and Plant Population Density}

\author{
Yacob Sirait', Wallace G. Pill ${ }^{2}$, and Walter E. Kee, Jr. \\ Department of Plant and Soil Sciences, University of Delaware, Newark, \\ DE 19717-1303
}

Additional index words. economic yield, harvest index, leaf area index, plant spacing

\begin{abstract}
Maffei-15' lima beans were subjected to three irrigation regimes (natural rainfall only, partial $=\mathbf{5 0} \mathrm{mm}$ each week of rain or irrigation from first-flower bud to harvest, and full $=\mathbf{5 0} \mathrm{mm}$ each week of rain or irrigation from planting to harvest), two between-row spacings $(38$ and $76 \mathrm{~cm})$, and two in-row plant spacings $(5$ and $10 \mathrm{~cm})$. The wider in-row spacing increased individual plant vegetative growth but had no effect on economic yield. The combination of 38-cm rows and partial irrigation provided the highest crop growth rate, plant dry matter, leaf area index, water-use efficiency, and economic yieid (equivalent to $3.3 \mathrm{t}^{\cdot} \mathrm{ha}^{-1}$ ).
\end{abstract}

Delaware currently produces $\approx 40 \%$ of the lima beans sold in the United States, although Delaware's current 4000 to 5000 ha devoted to lima beans is only about one-half the area devoted to lima beans 20 years ago (Kee, 1986). This diminished crop area and the lower yields of shelled green beans have made it difficult for processors in the area to receive adequate and reliable bean supplies.

Lima bean yield depends on the pod set on each raceme and the number of racemes, which is associated with plant size. Environmental conditions during the preflowering period determines plant size, whereas the environment determines the pod set during the flowering period (Cordner, 1934; Lambeth, 1950). Low lima bean yields are associated with profuse abscission of flower buds (Cordner, 1934). High night temperature (Rappaport and Carolus, 1956), low relative humidity, and low soil moisture lead to reduced pod set and retention (Fisher and Weaver, 1974). In Delaware, high humidity in the summer, which promotes pollination and pod set, favors lima bean production.

Rahn (1955) found that maintaining soil moisture $>75 \%$ field capacity increased lima bean yields in Delaware, and applying a single 25-mm irrigation at flowering increased yield

Received for publication 9 June 1993. Accepted for publication 13 Aug. 1993. Published as Miscellaneous Paper 1492 of the Delaware Agricultural Experiment Station. Mention of trade names in this publication does not imply endorsement by the Delaware Agricultural Experiment Station of products named nor criticism of similar ones not mentioned. Contribution 315 of the Plant and Soil Sciences Dept. The cost of publishing this paper was defrayed in part by the payment of page charges. Under postal regulations, this paper therefore must be hereby marked advertisement solely to indicate this fact.

'Graduate Research Assistant. Current address: Ministry of Agriculture, Jakarta, Indonesia.

${ }^{2}$ Professor. To whom reprint requests should be addressed.

${ }^{3}$ Cooperative Extension Vegetable Specialist. when a hot, dry period occurred during pod setting. In Delaware, higher economic yield of lima bean plants was achieved when irrigation was applied from flowering to harvest compared to when plants were not irrigated or given full-season irrigation (Ritter and Scarborough, 1990). Withholding irrigation during the vegetative stage led to reduced lima bean plant dry matter at anthesis, but it did not influence seed yield or shoot dry matter at harvest (Ziska et al., 1985). High-frequency, low-volume irrigation of lima beans increased uniformity of seed maturity but reduced seed yield (Smittle, 1979).

An inverse relationship between plant population density and lima bean economic yield has occurred with closer in-row spacing (Lachman and Snyder, 1943; Larson and Peng-Fi, 1948; Matthews, 1933) and closer row spacing (Larson and Peng-Fi, 1948) when irrigation either was not used or was not a factor. However, lima beans in the eastern United States typically have been planted in rows 76-91 cm apart with 7.5-to $10-\mathrm{cm}$ in-row spacing (Kee, 1986). These spacings were necessary to accommodate available harvesting equipment and to permit weed control by cultivation; however, narrow row spacings are now possible because of equipment that harvests lima beans in close row spacings and an effective broadleaf preemergence herbicide \{2-[4,5dihydo-4-methy1-4-(1-methyletihyl)-5-oxo1H-imidazol-2-yl]-5-ethyl-3-pyridinecarboxylic acid (Imazethapyr; American Cyanamid, Princeton, N.J.)\}.

Our objective in this experiment was to determine the effects of irrigation regime and plant population density on growth and economic yield of lima bean.

\section{Materials and Methods}

The study was conducted near Georgetown, Del. (lat. $38.7^{\circ} \mathrm{N}$, long. $75.3^{\circ} \mathrm{W}$ ) during JuneSept. 1992. According to the Univ. of Delaware Soil Testing Service, characteristics of the Kalmialoamy sand (fine loamy silicaceous, acid, thermic Typic Hapludult) were as follows: $1.0 \%(\mathrm{w} / \mathrm{w})$ organic matter; $\mathrm{pH}=5.9$; and available $\left(\mathrm{kg} \cdot \mathrm{ha}^{-1}\right) \mathrm{P}, 157 ; \mathrm{K}, 131 ; \mathrm{Mg}, 88$; $\mathrm{Ca}, 682 ; \mathrm{Mn}, 23$; and $\mathrm{Zn}, 3$.

Treatments for the $3 \times 2 \times 2$ factorial were 1) irrigation regime \{natural rainfall only [rain]; partial $=50 \mathrm{~mm}$ each week of rain or irrigation from first-flower bud [FFB, FFB = 28 days after planting (DAP)] to harvest; full $=50 \mathrm{~mm}$ each week of rain or irrigation from planting to harvest ]; 2) 38- and 76-cm between-row spacing; and 3)5- and $10-\mathrm{cm}$ in-row plant spacing. Impulse sprinklers $1.5 \mathrm{~m}$ above the soil surface dispersed $25 \mathrm{~mm}$ water at each irrigation.

Treatments were arranged as a split-splitplot with three replications. Irrigation regime was the main plot, subplot was between-row spacing, and sub-subplot was in-row spacing. Each sub-subplot consisted of four rows (76 $\mathrm{cm}$ between rows) or eight rows $(38 \mathrm{~cm}$ between rows) that were $6 \mathrm{~m}$ long. Border rows surrounded each sub-subplot.

Plots were hand-sown on 8 June 1992. Two days after planting, the plots received $90 \mathrm{~kg} \mathrm{~N} /$ ha from $14 \mathrm{~N}-3 \mathrm{P}-12 \mathrm{~K}$ (1-7-14). Imazethapyr herbicide was incorporated preplant at $36 \mathrm{~g}$ a.i./ha. Other pest control measures followed Univ. of Delaware recommendations (Univ. of Delaware, 1992). Air maxima and minima (1.8 $\mathrm{m}$ above the soil surface) and rainfall were recorded daily at a weather station $800 \mathrm{~m}$ from the plots.

At 38 and 69 DAP, plants from $30 \mathrm{~cm}$ of row were harvested from the central rows (outside the central $3 \mathrm{~m}$ of each row) to determine plant dry weight and leaf area. Leaf areas of these plants were determined by photocopying all leaves, cutting out the leaf images, and multiplying the weight of the paper leaf images by the paper weight : area ratio. Crop growth rate (CGR; CGR=grams of dry weight/ day) between the two harvest dates was calculated per plant and per plot. Plant dry weight per plot at 38 and 69 DAP was calculated by multiplying the average dry weight per plant by the number of plants in each plot. Leaf area indices (LAI) at 38 and 69 DAP were calculated by multiplying the average leaf area per plant by the number of plants in the plot and dividing this by the subtending land area (4.64 $\mathrm{m}^{2}$ for $76-\mathrm{cm}$ rows, $2.32 \times 2 \mathrm{~m}^{2}$ for $38-\mathrm{cm}$ rows).

At final harvest (85 DAP), plants were hand-pulled from the central $3 \mathrm{~m}$ of two inner rows in each plot and their total fresh weights determined. Flat, green pods and dry pods were separated from the plants, and the pod number and fresh weight of each category was determined. Beans were extracted from the green and dry pods, and the fresh weights of these shelled beans were determined. Harvest index (HI) was calculated as shelled, green lima bean fresh weight per plot as a percentage of plant (total shoot and extracted root) fresh weight per plot.

\section{Results and Discussion}

Full irrigation, compared to the other irrigation regimes, increased dry weight per plant or per plot by 38 DAP (Table 1). The dry 
Table 1. Vegetative growth of 'Maffei 15' lima bean plants between 38 and 69 days after planting (DAP) in response to irrigation regime (I), and in-row (IR) and between-row (BR) plant spacing.

\begin{tabular}{|c|c|c|c|c|c|c|c|c|}
\hline \multirow[b]{3}{*}{ Variable } & \multicolumn{4}{|c|}{ Plant dry wt } & \multirow{2}{*}{\multicolumn{2}{|c|}{ CGR (dry wt/day) }} & \multirow{2}{*}{\multicolumn{2}{|c|}{$\mathrm{LAI}^{z}$}} \\
\hline & \multicolumn{2}{|c|}{38 DAP } & \multicolumn{2}{|c|}{69 DAP } & & & & \\
\hline & (g/plant) & $\left(\mathrm{g} \cdot \mathrm{m}^{-2}\right)$ & (g/plant) & $\left(\mathrm{g} \cdot \mathrm{m}^{-2}\right)$ & (g/plant) & $\left(\mathrm{g} \cdot \mathrm{m}^{-2}\right)$ & $38 \mathrm{DAP}$ & $69 \mathrm{DAP}$ \\
\hline \multicolumn{9}{|l|}{ 38-cm BR } \\
\hline Rain only & 2.0 & 70 & 6.4 & 243 & 0.15 & 5.8 & 0.9 & 2.1 \\
\hline Partial & 2.0 & 77 & 14.3 & 547 & 0.41 & 15.7 & 1.4 & 3.7 \\
\hline Full & 3.1 & 123 & 12.3 & 447 & 0.31 & 10.8 & 2.1 & 3.5 \\
\hline \multicolumn{9}{|l|}{ 76-cm BR } \\
\hline Rain only & 2.0 & 34 & 9.3 & 154 & 0.25 & 4.0 & 0.5 & 1.3 \\
\hline Partial & 2.5 & 48 & 16.3 & 298 & 0.46 & 8.3 & 0.7 & 2.8 \\
\hline Full & 3.4 & 69 & 16.9 & 330 & 0.45 & 8.7 & 1.1 & 2.0 \\
\hline \multicolumn{9}{|l|}{$\mathrm{LSD}_{0.05}$} \\
\hline Same I & 1.3 & 35 & 5.6 & 76 & 0.19 & 4.9 & 0.5 & 1.0 \\
\hline Same BR & 1.5 & 46 & 5.0 & 67 & 0.17 & 4.3 & 0.7 & 1.3 \\
\hline \multicolumn{9}{|l|}{ IR } \\
\hline $5 \mathrm{~cm}$ & 2.1 & 79 & 9.6 & 351 & 0.25 & 9.1 & 1.3 & 2.6 \\
\hline \multirow{2}{*}{\multicolumn{9}{|c|}{ F test significances }} \\
\hline & & & & & & & & \\
\hline I & * & * & * & $* * *$ & $* * *$ & $* * *$ & $*$ & $* * *$ \\
\hline BR & NS & $* * *$ & NS & $* * *$ & * & $* * *$ & $* * *$ & $* * *$ \\
\hline IR & $* *$ & $*$ & $* * *$ & Ns & $* * *$ & NS & $* *$ & NS \\
\hline $\mathrm{BR} \times \mathrm{IR}$ & NS & NS & NS & NS & NS & NS & NS & NS \\
\hline $\mathrm{I} \times \mathrm{BR}$ & NS & NS & NS & $*$ & NS & $*$ & NS & $*$ \\
\hline $\mathrm{I} \times \mathrm{IR}$ & NS & NS & NS & NS & NS & NS & NS & NS \\
\hline $\mathrm{I} \times \mathrm{BR} \times \mathrm{IR}^{\prime}$ & NS & NS & NS & NS & NS & NS & NS & NS \\
\hline
\end{tabular}

${ }^{2} \mathrm{LAI}=$ leaf area indices.

'Partial irrigation $=5 \mathrm{~cm}$ water/week from 28 DAP to final harvest $(85 \mathrm{DAP})$; full irrigation $=5 \mathrm{~cm}$ water/ week from planting to final harvest.

***,**,*, ${ }^{\text {Ns }}$ Significant at $P \leq 0.001,0.01$, or 0.05 or nonsignificant, respectively. regime plots received only $61 \mathrm{~mm}$ of rainfall from planting until 38 DAP during which the average air minimum and maximum were 14.9 and $27.0 \mathrm{C}$, respectively (Fig. 1). The 70 $\mathrm{mm}$ of irrigation since FFB failed to increase the dry weight of plants subjected to partial irrigation relative to those plants receiving only rain by 38 DAP (Table 1). Between-row spacing had no effect on dry weight per plant by 38 DAP, but plant dry weight per plot was greater with $38-\mathrm{cm}$ between-row spacing than with 76-cm between-row spacing because of the greater population density. Although dry weight per plant by 38 DAP was lower with 5 -cm in-row spacing than with $10-\mathrm{cm}$ in-row spacing because of higher interplant competition, the higher plant population density with 5-cm spacing lead to greater plant dry weight per plot.

By 69 DAP, dry weights of plants subjected to partial and full irrigation were not significantly different but were $90 \%$ higher

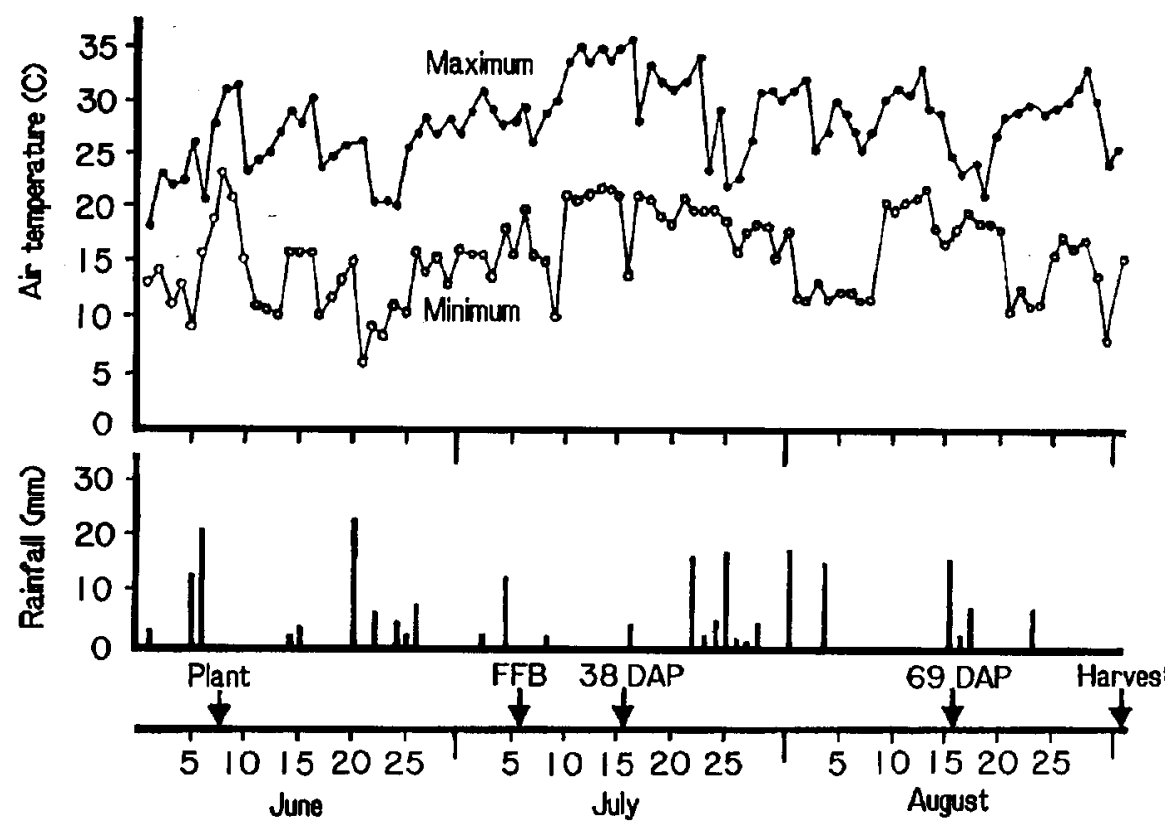

Fig. 1. Maximum and minimum daily air temperatures and rainfall from ulanting to harvest in 1992. Daily irrigation of the partial irrigation regime began at first flower bud (FFB), Crop growth rate was determined between 38 and 69 days after planting (DAP). than those of plants receiving rainfall only (Table 1). The rain-only plots received 105 $\mathrm{mm}$ of rainfall between 38 and $69 \mathrm{DAP}$, while the partial- and full-irrigation plots received $250 \mathrm{~mm}$ water from rain or irrigation. Plant dry weight per plot at 69 DAP was greater with 38 -cm between-row spacing than with $76-\mathrm{cm}$ between-row spacing, but this difference was greatest with partial irrigation. Ziska et al. (1985) obtained more shoot dry matter with lima bean plants grown in double rows (2-fold population density) on a $102-\mathrm{cm}$ bed than with lima bean plants grown in single rows. The lower individual plant dry weight with $5-\mathrm{cm}$ in-row spacing than with $10-\mathrm{cm}$ in-row spacing at 69 DAP (Table 1) was offset by the higher plant population density, so plant dry weight per plot was unaffected by in-row spacing.

Daily dry-weight gain per plant between 38 and 69 DAP was greater with partial or full irrigation than with-no irrigation, and with wider in-row and between-row spacings than with narrower spacings (Table 1). Both partial- and full-irrigation regimes gave higher CGR per plot than rain only, but $38-\mathrm{cm}$ rows increased CGR $88 \%$ relative to $76-\mathrm{cm}$ rows only in partial-irrigation plots. Because between-row spacing had no effect on daily dry-weight gain per plant in partially irrigated plots, the greater dry-weight gain per plot in $38-\mathrm{cm}$ rows (compared to $76-\mathrm{cm}$ rows) simply reflected the higher plant population density. At 38 DAP, dry weight per plant in $38-\mathrm{cm}$ rows was greater than dry weight per plant in $76-\mathrm{cm}$ rows under full irrigation, but the difference was not significant at 69 DAP. Thus, there was more interplant competition in 38$\mathrm{cm}$ rows than in 76-cm rows between 38 and 69 DAP, causing CGR per plant or CGR per plot to be unaffected by between-row spacing under full irrigation. In-row spacing had no effect on the CGR per plot, indicating that the higher plant population density with $5-\mathrm{cm}$ inrow spacing (compared to $10-\mathrm{cm}$ in-row spacing) compensated for the reduced growth of individual plants.

LAI at 38 DAP was increased by full irrigation compared to no irrigation, by $38-\mathrm{cm}$ between-row spacing compared to $76-\mathrm{cm}$ between-row spacing in partial- and full-irrigation plots, and by $5-\mathrm{cm}$ in-row spacing compared to $10-\mathrm{cm}$ in-row spacing (Table 1). Relative to no irrigation at $69 \mathrm{DAP}$, partial irrigation increased LAI in both $38-\mathrm{cm}$ and $76-\mathrm{cm}$ between-row spacings. Full irrigation increased LAI with $38-\mathrm{cm}$ rows but not $76-\mathrm{cm}$ rows. In-row spacing had no effect on LAI. Thus, the greatest potential photosynthetic surface area with the least water input was achieved with partial irrigation and $38-\mathrm{cm}$ between-row spacing.

In $38-\mathrm{cm}$ rows, both partial and full irrigation, compared to rainfall only, increased flat or green pod production equally (167\% and $95 \%$, respectively; Table 2). Irrigation regime had no effect on the number of green or flat pods per plot with $76-\mathrm{cm}$ rows. Full irrigation compared to other irrigation regimes, regardless of between-row spacing, increased dry pod count per plot and dry bean weight per 
Table 2. Pod and bean yields and harvest index (HI) of 'Maffei 15' lima beans at final harvest as influenced by irrigation regime (I) and between-row plant spacing (BR).

\begin{tabular}{|c|c|c|c|c|c|c|}
\hline \multirow[b]{2}{*}{ Variable $^{x}$} & \multicolumn{3}{|c|}{ No. pods/plot } & \multirow{2}{*}{$\begin{array}{c}\text { Dry lima beans } \\
\left(\mathrm{g} \cdot \mathrm{m}^{-2}\right)\end{array}$} & \multirow{2}{*}{$\begin{array}{c}\text { Green beans } \\
\left(\mathrm{g} \cdot \mathrm{m}^{-2}\right)\end{array}$} & \multirow{2}{*}{$\begin{array}{l}\mathrm{HI} \\
(\%)\end{array}$} \\
\hline & Flat & Green & Dry & & & \\
\hline \multicolumn{7}{|l|}{ 38-cm BR } \\
\hline Rain only & 25 & 120 & 1 & 0.2 & 117 & 8.2 \\
\hline Partial & 68 & 246 & 1 & 0.4 & 332 & 12.4 \\
\hline Full & 65 & 220 & 23 & 15.9 & 356 & 12.6 \\
\hline \multicolumn{7}{|l|}{ 76-cm BR } \\
\hline Rain only & 24 & 92 & 0 & 0.2 & 117 & 10.7 \\
\hline Partial & 33 & 162 & 1 & 0.4 & 226 & 14.5 \\
\hline Full & 45 & 134 & 10 & 6.5 & 194 & 13.4 \\
\hline \multicolumn{7}{|l|}{$\mathrm{LSD}_{0.05}$} \\
\hline Same I & 37 & 298 & 14 & 6.0 & 99 & 3.6 \\
\hline Same BR & 44 & 371 & 15 & 10.8 & 132 & 6.9 \\
\hline \multicolumn{7}{|c|}{$F$ test significances } \\
\hline I & NS & * & $* *$ & * & * & * \\
\hline BR & $* *$ & $* * *$ & NS & NS & $* * *$ & NS \\
\hline IR & NS & NS & NS & NS & NS & NS \\
\hline $\mathrm{BR} \times \mathrm{IR}$ & NS & NS & NS & NS & NS & NS \\
\hline $\mathrm{I} \times \mathrm{BR}$ & $*$ & * & NS & NS & $* *$ & NS \\
\hline $\mathrm{I} \times \mathrm{IR}$ & NS & NS & NS & NS & NS & NS \\
\hline $\mathrm{I} \times \mathbf{B R} \times \mathbf{I R}$ & NS & NS & NS & NS & NS & NS \\
\hline
\end{tabular}

${ }^{2}$ Partial irrigation $=5 \mathrm{~cm}$ water/week from 28 DAP to final harvest ( 85 DAP); full irrigation $=5 \mathrm{~cm}$ water/week from planting to final harvest.

***,**,*, ${ }^{\text {NS }}$ Significant at $P \leq 0.001,0.01$, or 0.05 or nonsignificant, respectively.

plot, indicating hastened crop maturation. In contrast to the results of Lambeth ( 1950), who noted greater variation of maturity due to flower and small-fruit abortion when lima beans plants were subjected to soil water stress, we observed no reduction in synchrony of economic yield of plants not provided irrigation.

Shelled green lima bean weight per plot, similar to the number of green pods per plot, was increased equally by partial or full irrigation relative to rainfall only in $38-\mathrm{cm}$ rows, but it was unaffected by irrigation regime in $76-\mathrm{cm}$ rows (Table 2). Thus, for economic yield to be increased by the narrower between-row spacing, partial or full irrigation must be supplied. Larson and Peng-Fi Li(1948) noted that, depending on location in Pennsylvania, $51-\mathrm{cm}$ rows, compared to $76-\mathrm{cm}$ rows, produced more, the same, or less economic yield. However, in contrast to our results, in which in-row spacing had no effect on economic yield, these researchers found that economic yield increased as in-row plant spacing decreased from 15 to 5 $\mathrm{cm}$. The higher economic yield at the higher population density was associated with greater plant weights per plot. A positive correlation between lima bean seed yields and shoot dry matter production is documented (Fisher and Weaver, 1974; Lambeth, 1950; Rappaport and Carolus, 1956; Smittle, 1986; Ziska et al., 1985). Ritter and Scarborough (1990) noted higher lima bean economic yield with partial than with full irrigation at $76-\mathrm{cm}$ between-row spacing, in contrast to our study, in which economic yields were equal with these two irrigation regimes.

We observed that pods grew lower in the canopy with $38-\mathrm{cm}$ between-row than with 76- $\mathrm{cm}$ between-row spacing, a response to higher plant population density observed in soybean [Glycine max (L.) Merrill] (Hanway and Thompson, 1967). The higher economic yield with $38-\mathrm{cm}$ between-row spacing compared to $76-\mathrm{cm}$ between-row spacing maybe explained, in part, by greater pod shading within the canopy as a result of higher LAI and lower pod position. Shade may reduce temperature and increase relative humidity within the canopy, conditions that favor increased pod set and retention (Fisher and Weaver, 1974). In our study, the average daily air maximum and minimum $1.8 \mathrm{~m}$ above the soil surface between FFB and final harvest were 29.3 and $17.6 \mathrm{C}$, respectively, but maxima reached 35C (Fig. 1).

HI was affected only by irrigation regime. Partial and full irrigation gave higher values than rainfall only (Table 2). Thus, the combination of $38-\mathrm{cm}$ rows and partial irrigation, compared to $76-\mathrm{cm}$ rows and full irrigation, did not increase the efficiency of economic yield production but gave greater CGR, plant dry matter, and LAI.

Full irrigation and 76-cm row spacing gave economic yields equivalent to $1.9 \mathrm{t} \cdot \mathrm{ha}^{-1}$, similar to the average yield in Delaware. By decreasing between-row spacing to $38 \mathrm{~cm}$, economic yields were increased to $3.3 \mathrm{t} \cdot \mathrm{ha}^{-1}$ for partial irrigation and $3.6 \mathrm{t} \cdot \mathrm{ha}^{-1}$ for full irrigation (yields that approach the average 4.0 $\mathrm{t} \cdot \mathrm{ha}^{-1}$ in California).

This study's results show that $10-\mathrm{cm}$ in-row and $38-\mathrm{cm}$ between-row spacing $(258,000$ plants/ha) give the highest economic lima bean yield in southern Delaware. However, irrigation must be supplied to realize the yield increase from this narrow row spacing. Because economic yields were the same with full or partial irrigation, partial irrigation represents greater water-use efficiency.

\section{Literature Cited}

Cordner, H.B. 1934. External and internal factors affecting blossom drop and set of pods in lima beans. Proc. Amer. Soc. Hort. Sci. 30:571-576.

Fisher, V.J. and C.K, Weaver. 1974. Flowering, pod set, and pod retention of lima bean in response to night temperature, humidity, and soil moisture. J. Amer. Soc. Hort. Sci. 99:448-450.

Hanway, J.J. and H.E. Thompson. 1967, How a soybean plant develops. Spec. Rpt. 53. Iowa State Univ. Coop. Ext. Serv., Ames.

Kee, Jr., W.E, 1986. Lima beans show steady success in Delaware. Amer. Veg. Grower 34:7879 .

Lachman, W.H. and G.B. Snyder. 1943. Experiments with lima beans. Proc. Amer. Soc. Hort. Sci. 42:554-556.

Lambeth, V.N. 1950. Some factors influencing pod set and yield of the lima bean. Univ. of Missour Agr. Expt. Sta. Res. Bul. 466.

Larson, R.E. and L. Peng-Fi Li. 1948. The influence of various row and plant spacings on yield of lima beans. Proc. Amer. Soc. Host. Sci. 51:479485.

Matthews, W.A. 1933. The influence of planting distances on the yield of snap and lima beans. Proc. Amer. Soc. Hort. Sci. 30:567-570,

Rahn, E.M. 1955. The effect of certain cultural and growth regulator treatments on pod-set and yield of lima beans. Proc. Amer. Soc. Hort. Sci. 66:298-307.

Rappaport, L. and R.L, Carolus. 1956. Effects of night temperature at different stages of development on reproduction in the lima bean. Proc. Amer. Soc. Hort. Sci. 67:421-428,

Ritter, W.F. and R.W. Scarborough. 1990. Irrigation management of lima beans. Trans. Amer. Soc. Agr. Eng. Paper 90-2006.

Smittle, D.A. 1979. Response of lima bean (Phaseolus lunatus L.) to irrigation, nitrogen fertilization, and seed grading. J. Amer. Soc. Hon. Sci. 104: 176-178,

Smittle, D.A. 1986. Influence of cultivar and temperature on lima bean yield and quality. J. Amer. Soc. Hort. Sci. 111:655-659.

Univ. of Delaware. 1992. 1992 Commercial vegetable production recommendations. Ext. Bul. 137. Newark, Del.

Ziska, L.H., A.E. Hall, and R.M. Hoover. 1985. Irrigation management methods for reducing water use of cowpea and lima bean, while maintaining seed yield at maximum level. Irr. Sci. 6:223-239, 